\title{
Professor Sir Ludwig Guttmann, FRS
}

\author{
Founder and First Editor of 'Paraplegia': Centenary Anniversary of his Birth
}

It is very important and appropriate to acknowledge the Centenary Anniversary of the birth of the distinguished Founder and first Editor of the official journal of the International Medical Society of Paraplegia (IMSOP).

The concept of having a specialized journal to encompass the multifaceted speciality concerning the basic science and the clinical aspects of spinal neural injuries and diseases came naturally to (at that time known as) Dr Guttmann, having created the International Medical Society of Paraplegia in 1961. It was logical to have an international journal 'Paraplegia' (in 1996 the title of the journal was changed to Spinal Cord). In the foreword to the first edition of the Journal, called 'Paraplegia', in Volume 1, Number 1, April 1963, Dr Guttmann wrote:- 'Ever since the Stoke Mandeville Games - the annual sports festival of the paralysed-became an international event in 1952, Scientific Meetings have been held each year on that occasion. These gave physicians, surgeons and research workers the opportunity to exchange experiences in the intricate problems concerned with injuries and diseases of the spinal cord. As the years went by, the need to form an International Medical Society of Paraplegia became more and more manifest, and in 1961 the Society was founded.

With the formation of the Society arose a distinct desire for a journal which would serve as a structure for uniting the Society's widely scattered members and above all be designed as a central international source of information for all groups of physicians, surgeons and other scientific workers actively engaged or interested in the manifold aspects of paraplegia and quadriplegia.

Considerable advances have been made since World War II in this hitherto neglected and depressing subject, which involves so many aspects of medicine and surgery. Up till now, the steadily increasing amount of published work in this field has been scattered in many journals, making a heavy claim on the time of the reader wishing to become familiar with current literature and new developments.

It is to provide an international forum for an easy interchange of ideas for all those responsible for the welfare of our paralysed fellow men, as well as to promote further elucidation of the many and varied aspects of this problem, that this new journal Paraplegia is dedicated. Long may it flourish!'

And, as we know, now some 36 years later, flourish it did!
To set the scene in a personal manner, I have a clear, vivid memory of being contacted one day in 1962, by Dr Guttmann and invited to meet with $\mathrm{Mr}$ Charles Macmillan, Publisher, of E and S Livingstone in their premises in Teviot Place, Edinburgh, across the road from the Medical School. As usual, Ludwig was well prepared, and knew precisely what he was seeking. Mr Macmillan, a wise and canny Scot, appreciated the reputation and eminence of $\mathrm{Dr}$ Guttmann who wanted to launch a new, international medical journal, but was aware of the possible risks if such a journal was unsuccessful, as even a good journal with excellent material can fail, as was known by $\mathrm{Mr}$ Macmillan. The publisher noted the multispeciality and international involvement, with the support of many specialists and many specialities including neurosurgery, urology and orthopaedic surgery, and with Dr Guttmann as 'the pioneer commander'; Charles Macmillan was not really difficult to convince, and thus there was another feather in the cap of this outstanding doctor, who would be the first Editor of 'Paraplegia'.

The rest 'may be history' but the initiation and the development of this quite new, specialized medical journal must be recorded. In the special, 70th Sir Ludwig Guttmann Birthday issue there were special tributes from several distinguished people, ('Paraplegia', 1969-1970; 7: 143-172), including one from Mr Charles Macmillan, who mentioned the excitement for a publisher for an entirely new journal. His initial, understandable concern regarding any new journal was: "would the quality of the articles command the attention of the specialists in most countries throughout the world'? He said that the first few years suggest our aims have been achieved, and he paid tribute to Sir Ludwig and asked if he might refer him to the Book of Psalms, Number 92: 'The righteous will flourish as the palm tree. They shall still bring forth fruit in old age'.

Mr Jim Cosbie Ross (a Urological Surgeon) and I (indeed like Dr Guttmann, a neurosurgeon) were appointed Assistant Editors, and there was an Editorial Board, encompassing different specialities and different countries. To begin with there were four issues a year (quarterly), increasing in 1980 to six a year (bimonthly).

Sir Ludwig was a dynamic, unique person, with remarkable tenacity of purpose and of achievements; indeed a man of vision. In the special 80th Birthday issue of the journal ('Paraplegia' 1979; 17) there were tributes and special scientific papers in honour of Sir 
Ludwig. Mr Cosbie Ross and I in our Editorial praised him for his important researches and his tireless important activities for spinal paralysed people: 'Strong in will, to strive to seek, to find and not to yield'.

There was great enthusiasm for the journal, which attracted many high quality scientific contributions, and indeed the pages over the years provide a panoramic account and view of the main interests and developments in all aspects of spinal disorders. Several topics were controversial, and indeed some of them remain so, and this is indicated in articles and in something that pleased Sir Ludwig: publication of verbatim, often very lively! discussions on published papers-ones which had been read at an annual scientific meeting of IMSOP; peoples' views, and certainly Sir Ludwig's were aired with zest! As time went on this feature of the journal faded and was then discontinued; in any event they had not been peerreviewed, and also many scientific papers were being submitted from authors who had not been involved with an IMSOP meeting, and indeed may not have been a member of that Society. Another feature was to have an abstract at the end of each paper in three languages-English, French and German.
Although Sir Ludwig retired from the (British) National Health Service in 1967, he continued to be active in many medical and paramedical spheres, including Editorship of 'Paraplegia', indeed up to the time of his death, in his 81st year, in 1980 .

It has been a privilege and a wonderful experience to have had the opportunity to know Sir Ludwig, as a personal friend and mentor. In a striking, determined and at times dramatic way, he influenced and inspired many people worldwide. He was certainly a man of vision and of ideas, but was always undaunted and had no place for bureaucrats.

It was said of Sir Ludwig: 'Let us now praise famous men, and our fathers who beget us; (The Apocrypha, Ecclesiasticus $\mathrm{x} / \mathrm{iv}, 1)$.

The journal is a fitting memorial to Sir Ludwig, the Founder and first Editor.

Phillip Harris Emeritus Editor*

*Mr Phillip Harris was elected Editor in 1980, retiring in 1997. 